\title{
Restriction Fragment Length Polymorphism of 195 bp Repeated Satellite DNA of Trypanosoma cruzi Supports the Existence of Two Phylogenetic Groups
}

\author{
Brigitte Bastrenta $^{+}$, Marie France Bosseno, Christian Barnabé, \\ Michel Tibayrenc, Simone Frédérique Brenière
}

\author{
UMR CNRS/ORSTOM 9926: “Génétique Moléculaire des Parasites et des Vecteurs”, ORSTOM, BP 5045, \\ 34032 Montpellier Cedex 01, France
}

The restriction fragment length polymorphism of the $195 \mathrm{bp}$ repeated DNA sequence of Trypanosoma cruzi was analyzed among $23 \mathrm{~T}$. cruzi stocks giving a reliable picture of the whole phylogenetic variability of the species. The profiles observed with the enzymes Hinf I and Hae III were linked together and supported the existence of two groups. Group 1 shows a 195 bp repeated unit (Hinf I) and high molecular weight DNA (Hae III), while group 2 presents a ladder profile for each enzyme, which is a characteristic of tandemly repeated DNA. The two groups, respectively, clustered stocks pertaining to the two principal lineages evidenced by isoenzyme and RAPD markers. The congruence among these three independent genomic markers corroborates the existence of two real phylogenetic lineages in $\mathrm{T}$. cruzi. The specific monomorphic profiles for each major phylogenetic lineage suggest the existence of ancient sexuality and cryptic biological speciation.

Key words: Trypanosoma cruzi - satellite DNA - 195 bp repeat unit

Satellite DNA, as distinct from kinetoplast DNA, was observed in Trypanosoma cruzi (the causative agent of Chagas disease) and T. brucei protozoan parasites (Borst et al. 1980). T. cruzi satellite DNA located in minichromosomes constituted approximatively $9 \%$ of the nuclear DNA and was made of a long tandem array of $195 \mathrm{bp}$ repeated (Lanar et al. 1981, Castro et al. 1981, Sloof et al. 1983). Satellite DNA diverges rapidly from one species to another and provides a useful tool to distinguish close related species of the genus trypanosome (Ole-MoiYoi 1987, Dickin \& Gibson 1989, Jarman \& Wells 1989, Brenière et al. 1993a,b). Moreover, T. cruzi satellite DNA is a target for a specific PCR-based diagnosis of Chagas disease in blood samples (Gonzales et al. 1984).

The genetic variability of $T$. cruzi is significant as evidenced by isoenzyme (Miles et al. 1978, Romanha et al. 1979, Tibayrenc et al. 1981, 1986), restriction fragment length polymorphisms (RFLP) of kinetoplast DNA (Morel et al. 1980, Tibayrenc \& Ayala 1987), DNA fingerprinting (Macedo et al. 1992) and random amplification of polymor-

\footnotetext{
${ }^{+}$Corresponding author. Present address: ORSTOM, Mission Bolivia, Casilla 9214, La Paz Bolivia. Fax: 591-22258 46. E mail: Bastrenta@ns.megalink.com

Received 17 September 1998

Accepted 27 November 1998
}

phic DNA (RAPD) (Tibayrenc et al. 1993, Steindel et al. 1993). T. cruzi is present as numerous natural clones (Tibayrenc \& Ayala 1988) clustered in two principal phylogenetic lineages each highly polymorphic (Tibayrenc et al. 1993, Souto et al. 1996).

In this work satellite DNA RFLPs were compared between $T$. cruzi stocks previously characterized by RAPD (7 loci) and multilocus enzyme electrophoresis (MLEE, 22 loci), using the $195 \mathrm{bp}$ repeated as probe. The observed dimorphism of $195 \mathrm{bp}$-RFLP preserved the two lineages giving a further evidence of a clear upper subdivision of $T$. cruzi taxon.

\section{MATERIALS AND METHODS}

Samples and genetic characterization - The Table summarizes places, and host origins of 24 stocks. Among them, 18 were previously characterized using 22 isoenzyme loci (Table and unpublished data) and 7 RAPD loci (Tibayrenc et al. 1993). Five additional stocks were analyzed at the same 29 loci. Genetic differences between stocks were estimated by Jaccard's distance (Jaccard 1908). A distance matrix was established from combined RAPD and MLEE data. Phylogenetic relationships were evaluated by the clustering method using the UPGMA (unweighted pair-group method with arithmetic averages) algorithm method (Sokal \& Sneath 1973). The accuracy of phylogenetic divisions was tested by a bootstrap analysis; we selected the A0087 stock as an 
TABLE

Origin, of the 24 Trypanosoma cruzi stocks, studied

\begin{tabular}{|c|c|c|c|}
\hline$\underline{\text { Stocks }}$ & Host & Locality & $\mathrm{MLEE}^{b}$ \\
\hline Cutia cl1 ${ }^{a}$ & Dasylprocta aguti & Espírito Santo, Colatina, Brazil & 1 \\
\hline Cuica cl1 ${ }^{a}$ & Philander opossum & São Paulo, Riberão Preto, Brazil & 1 \\
\hline $\mathrm{SO} 34 \mathrm{cl}^{a}$ & Triatoma infestans & Potosi, Toropalca, Bolivia & 1 \\
\hline Gamba cl1 ${ }^{a}$ & Didelphis azarae & São Paulo, Riberão Preto, Brazil & 2 \\
\hline $\mathrm{P} 11 \mathrm{cl} 3^{a}$ & Human & Cochabamba, Bolivia & 1 \\
\hline Esquilo cl1 ${ }^{a}$ & Sciurus aestuans ingrami & São Paulo, Franca, Brazil & 1 \\
\hline SP104 $\operatorname{cl1}^{a}$ & Triatoma spinolai & IVa region, Combarlalá, Chile & ND \\
\hline $\mathrm{P} 209 \mathrm{cl}^{a}$ & Human & Chuquisaca, Sucre, Bolivia & 1 \\
\hline $13379 \mathrm{cl}^{a}$ & Human & Santa-Cruz, Bolivia & 1 \\
\hline $\mathrm{X} 10 \mathrm{cl} 1 \mathrm{Z1}^{a}$ & Human & Pará, Belém, Brazil & 1 \\
\hline OPS4 & Didelphis marsupialis & Carabobo, El Yagual, Venezuela & 1 \\
\hline $\mathrm{CBB} \mathrm{cl}^{a}$ & Human & IVa region, Tulahuén, Chile & 1 \\
\hline TU18 $\mathrm{cl} 2^{a}$ & Triatoma infestans & Potosi, Bolivia & ND \\
\hline Esmeraldo cl3 $\mathrm{Z2}^{a}$ & Human & Bahia, São Felipe, Brazil & 1 \\
\hline $\mathrm{SO} 3 \mathrm{cl}^{a}$ & Triatoma infestans & Potosi, Otavi, Bolivia & 3 \\
\hline $\mathrm{MN} \operatorname{cl} 2^{a}$ & Human & IVa region, -, Chile & 1 \\
\hline $\mathrm{SC} 43 \mathrm{cl}^{a}$ & Triatoma infestans & Santa-Cruz, Santa-Cruz, Bolivia & 1 \\
\hline $\mathrm{NR} \operatorname{cl} 3^{a}$ & Human & IIIa region, Salvador, Chile & 1 \\
\hline TPK1 & Triatoma infestans & La Paz, Khala Khala, Bolivia & 3 \\
\hline Bug $2148 \mathrm{cl}^{a}$ & Triatoma infestans & Rio Grande do Sul, Brazil & ND \\
\hline Tulahuen FKIIA $\mathrm{cl} 2^{a}$ & Human & IVa region, Tulahuen, Chile & 1 \\
\hline M6241 $\mathrm{cl6}^{a}$ & Human & Pará, Belém, Brazil & 1 \\
\hline Can III cl1 Z3 $3^{a}$ & Human & Pará, Belém, Brazil & 1 \\
\hline A0087 & Didelphis marsupialis & Montsinery, French Guiana & 4 \\
\hline
\end{tabular}

$a$ : laboratory cloned stocks; $b$ : previous isoenzyme characterization for 15-20 enzymatic loci, 1: Tibayrenc et al. (1993); 2: Tibayrenc \& Ayala (1988); 3: Brenière et al. (1991); 4: Lewicka et al. (1995); ND: not done.

outgroup because it is genetically unrelated to other stocks (Felsenstein 1985).

Restriction fragment length polymorphism DNAs were phenol chloroform extracted from 100 mg of parasites (Véas et al. 1991). A complete digestion of $3 \mu \mathrm{g}$ of the DNA preparation was obtained overnight with $5 \mathrm{UI} / \mu \mathrm{g}$ of Eco RI, Hae III and Hinf I restriction enzymes (Boehringer, France). Digested DNAs were electrophoresed in a $20 \mathrm{~cm}$-long $0.8 \%$ agarose gel in $1 \mathrm{X}$ TBE at $30 \mathrm{~V}$ for $16 \mathrm{hr}$ and transferred by capillarity onto nylon membranes Hybond $\mathrm{N}+{ }^{\mathrm{TM}}$ (Amersham, Buckinghamshire, UK) (Sambrook et al. 1989).

The 195 bp probe was purified by electroelution from NR cl3 stock PCR products obtained with TCZ1 (5'CGAGCTCTTGCCCACACGGGTGCT3') and TCZ2 (5'CCTCCAAGCAGCGGATAGTT CAGG3') primers (Genset, Paris, France). These primers were designed to anneal sites at the extremities of the $T$. cruzi satellite DNA repeated unit (Sloof et al. 1983, Moser et al. 1989). The concentration was assessed by electrophoresis.

Labeling and hybridization were performed with the enhanced chemiluminescence gene detection system (ECL, Amersham, Buckinghamshire, UK). Briefly, the membranes were pre-hybridized in the hybridization buffer $\left(0.25 \mathrm{ml} \mathrm{cm}^{-2}\right)$ for 20 min at $42^{\circ} \mathrm{C}$. The purified probe $\left(20 \mathrm{ng} \mathrm{ml}^{-1}\right.$ of buffer) was labeled for $10 \mathrm{~min}$ at $37^{\circ} \mathrm{C}$. Hybridization was carried out overnight at $42^{\circ} \mathrm{C}$. The membranes were then washed twice for $20 \mathrm{~min}$ at $42^{\circ} \mathrm{C}$, under high stringent conditions (6 $\mathrm{M}$ urea, $0.1 \%$ SDS, $0.1 \mathrm{SSC}$ ) and twice for $10 \mathrm{~min}$ in a $2 \mathrm{x} \mathrm{SSC}$ at room temperature. The detection was performed in autoradiography films (Hyperfilms ${ }^{\mathrm{TM}}-\mathrm{MP}$, Amersham, Buckinghamshire, UK).

\section{RESULTS}

RFLP patterns - Twenty four T. cruzi DNAs stocks digested by Eco R1, Hae III and Hinf I restriction enzymes were hybridized with the $195 \mathrm{bp}$ probe. Three different hybridization patterns were observed: (1) a hybridization limited to high molecular weight DNAs associated with few smaller bands for some stocks (Fig. 1a,b); showing the scarcity of the restriction site in satellite DNA. This pattern was observed for all the DNAs stocks digested by Eco RI and half the stock DNAs digested by Hae III; (2) one main intense band of $195 \mathrm{bp}$ corresponding to the monomer of the satellite DNA (Fig. 1c).; showing the presence of the restriction site in each repeat unit. This pattern was observed 
for half of the DNAs stocks digested by Hinf I; (3) a ladder of $195 \mathrm{bp}$ polymer bands (18 detectable polymers) (Fig. 1b,c), was observed for half of the DNAs stocks digested by Hinf I and Hae III. The clear interpretation of this profile is a tandem array of nearly identical elements, many of which lack the Hinf I and Hae III sites as a result of sequence heterogeneity.

The Eco RI RFLP did not show a clear polymorphism due to the scarcity of the restriction site. Two distinct patterns were observed for the Hinf I and Hae III RFLPs. Moreover the stocks showing a Hinf I unit always presents Hae III high molecular weight profiles and those with a Hinf I ladder also presents Hae III ladder patterns. Thus the stocks were clustered in only two different RFLP groups.

Clustering and RFLP $195 \mathrm{bp}$ - Fig. 2 presents the dendrogram constructed from RAPD and MLEE data (29 loci) and shows two principal lineage named 1 and 2. Lineage 1 and 2 occur 100 and 83.2 times out of 100 replicates, respectively (bootstrap analysis). The stocks belonging to each lineage (1 and 2) present a specific RFLP pattern, except Can III stock which was clustered in lineage 2 but has a RFLP pattern identical to the stocks of lineage 1 .

\section{DISCUSSION}

Taxonomical considerations - The present phylogenetic study, plotting RAPD and MLEE data together, allows an analysis of 29 loci and clusters the stocks in two distinct lineages. The same lineages were previously evidenced separately by each marker (Tibayrenc et al. 1993). We introduced the bootstrap analysis to test the confidence limits of the two present groups. The bootstrap places high confidence limits only for lineage $2(100 \%)$, while the monophyly of lineage 1 is more uncertain (83.2\%); a group can be considered monophyletic if it occurs in at least $100-5 / n-1$ percent of the bootstrap estimated, where $\mathrm{n}$ is the number of groups (Felsenstein 1985).

The analysis of $T$. cruzi RFLP satellite DNA polymorphism, shows only two distinct profiles among the same set of T. cruzi stocks. This dimorphism preserves the two lineages with the exception of Can III stock which presents a lineage 2 RFLP profile. If we consider the polymorphism of satellite DNA, Can III stock, belonging to zymodeme 3 (Z3), is more related to lineage 2 that includes the X10 cl1 stock belonging to zymodeme 1 (Z1) (Miles et al. 1977, 1981). Pioneering work showed that Z1 and Z3 have a closer relationship (Ready \& Miles 1980). Moreover, in Brazilian, French Guianan and Bolivian (unpublished data) sylvatic cycles, stocks belonging to Z1 and Z3 zymodemes are largely represented (Miles et al. 1981, Lewicka et al. 1995, Carrasco et al. 1996). The profile showed by 195 bp RFLP seems to support a common evolution of Z1 and Z3 zymodemes.

In conclusion, the satellite DNA polymorphism would truly support the presence of two lineages

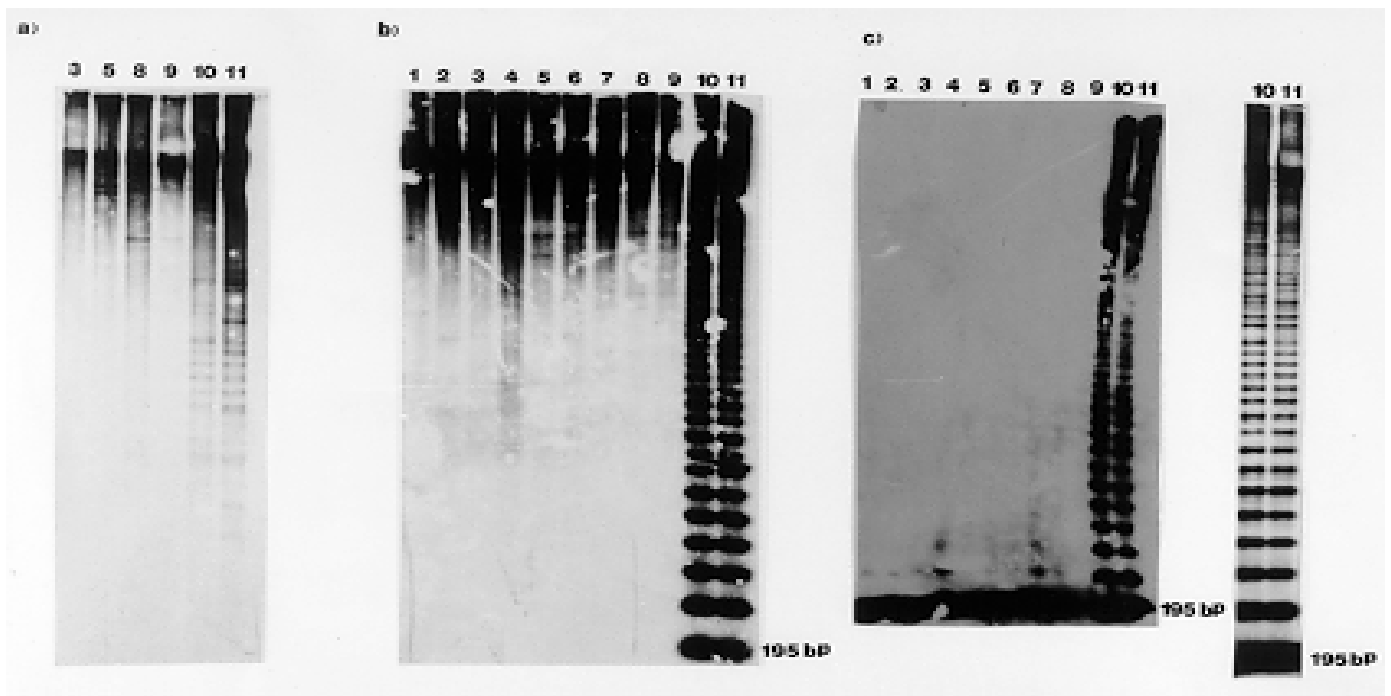

Fig. 1: autoradiographs of Southern blots showing typical banding observed when (a) Eco RI (b) Hae III and (c) Hinf I digests of DNA from Trypanosoma cruzi stocks, hybridized with the $195 \mathrm{bp}$ repeated probe.

Lanes 1 to 9: P209 cl1, Sp104 cl1, Cutia cl1, Gamba cl1, 13379 cl7, P11 cl3, So34 cl4, Cuica cl1, Esquilo cl1. These stocks belong to lineage 2 evidenced by RAPD and MLEE markers and present a unit profile for Hinf I and high molecular weight for Hae III. Lanes 10 to 11: Sc43 c11, Bug 2148 cl1. These stocks belong to lineage 1 and present a ladder profile for Hinf I and Hae III. 


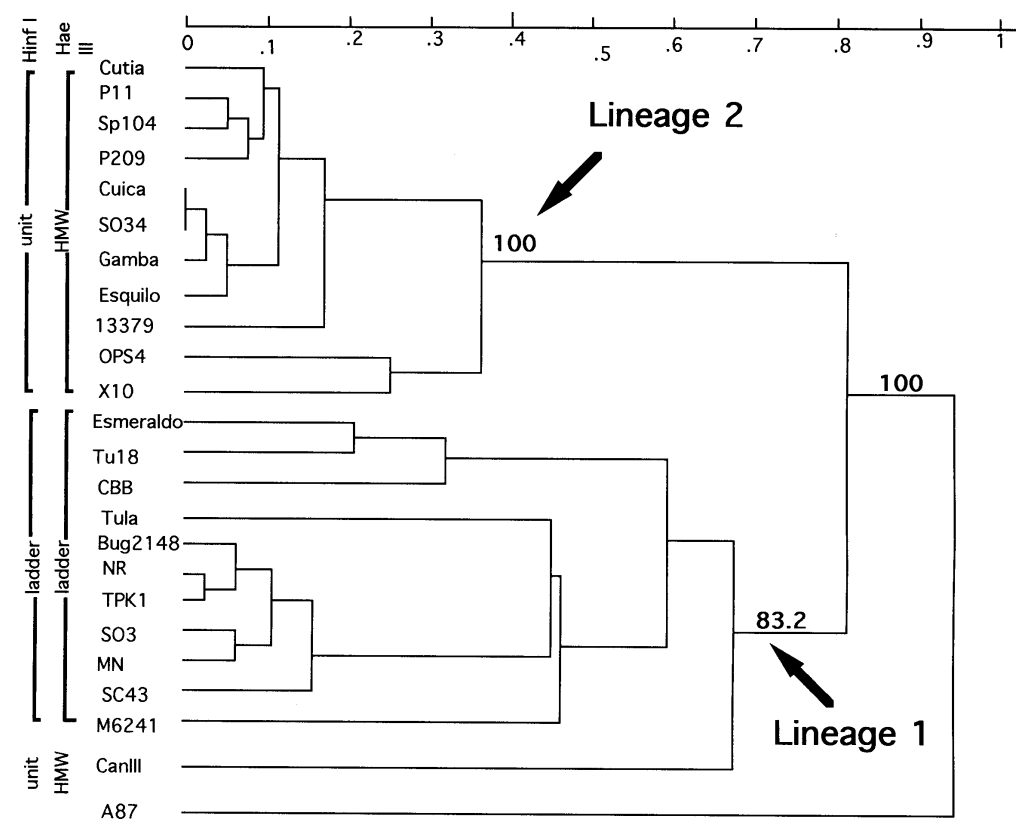

Fig. 2: dendrogram of the 24 Trypanosoma cruzi stocks constructed by UPGMA method from Jaccard's distances obtained by RAPD and MLEE (29 loci) method joined toghether. The values of bootstrap are indicated for the two lineages. Unit, ladder and high molecular weight (HMW) refer to the RFLP profile obtained with Hinf I and Hae III restriction enzymes.

in the natural T. cruzi population. This attractive result deserves to be investigated in a larger set of T. cruzi stocks of geographic and host diversified origins.

What is the origin of the two major phylogenetic lineages of T. cruzi? - A classical mechanism of homogenization of tandem repeat is the recombination that occurs constantly in sexual species. According to our results, T. cruzi satellite DNA shows no polymorphism of its tandem repeated sequences within each of the two major phylogenetic lineages described (Tibayrenc 1995, Souto et al. 1996). This drastic satellite DNA sequence divergence between the two phylogenetic groups, together with their homogeneity within each of them, suggests events of cryptic speciation in a basically sexual species followed by a sequence homogenization in each species. Such a hypothesis of a cryptic biological speciation has been proposed (Tibayrenc et al. 1984) in order to explain the origin of the two T. cruzi major phylogenetic lineages. As mentioned above, a great homogeneity of sequences is expected within a biological species, if one assumes a tandem arrangement of sequences. The present populations of $T$. cruzi show a typical clonal structure. In case of long-lasting clonal evolution, we would expect a divergence of the repeated sequences between clones due to the accumulation of divergent muta- tions not only between the two major phylogenetic lineages but also within each of them. The satellite DNA data, therefore, suggest the existence of ancient sexuality and cryptic biological speciation within $T$. cruzi followed by a more recent clonal evolution in the two lineages. Nevertheless, isoenzyme and RAPD data do show considerable genetic heterogeneity and strong linkage disequilibrium within each of the major phylogenetic lineages, which supports the hypothesis that they are the result of a long-term clonal evolution with only occasional events of hybridization followed by clonal propagation of the hybrids (Tibayrenc 1995, Bogliolo et al. 1996, Brisse et al. 1998). An alternative explanation for the satellite DNA monomorphism within each of the two lineages is that in $T$. cruzi, and possibly in other kinetoplastid parasites, these sequences have a specific evolutionary rate and a slow molecular clock. In this case, the specific monomorphic profiles recorded in the present study for each major phylogenetic lineage would correspond to common-place synapomorphic characters, as it is the case for many isoenzyme, RAPD, and mini-exon characters (Tibayrenc 1995, Souto et al. 1996, Brisse et al. 1998).

\section{REFERENCES}

Bogliolo AR, Lauriapires L, Gibson WC 1996. Polymorphisms in Trypanosoma cruzi: evidence of genetic recombination. Acta Trop 61: 31-40. 
Borst P, Fase-Fowler F, Frasch ACC, Hoeijmakers JHJ, Weijers PJ 1980. Characterization of DNA from Trypanosoma brucei and related trypanosomes by restriction endonuclease digestion. Mol Biochem Parasitol 1: 221-246.

Brenière SF, Bosséno MF, Barnabé C, Urdaneta-Morales S, Tibayrenc M 1993a. Copy number differences in the 195 bp repeated satellite DNA from Trypanosoma cruzi and Trypanosoma rangeli: potential uses for epidemiological surveys. Mem Inst Oswaldo Cruz 88: 163-165.

Brenière SF, Bosséno MF, Barnabé C, Urdaneta-Morales S, Tibayrenc M 1993b. Population genetics of Trypasoma cruzi and Trypanosoma rangeli: taxonomical and epidemiological purpose. Biol Res 26: 27-33.

Brisse S, Barnabé C, Tibayrenc M 1998. Trypanosoma cruzi: how many relevant phylogenetic subdivisions are there? Parasitol Today 14: 178-179.

Carrasco HJ, Frame IA, Valente SA, Miles MA 1996. Genetic exchange as a possible source of genomic diversity in sylvatic populations of Trypanosoma cruzi. Am J Trop Med Hyg 54: 418-424.

Castro C, Craig SP, Castaneda M 1981. Genome organization and ploidy number in Trypanosoma cruzi. Mol Biochem Parasitol 4: 273-282.

Dickin SK, Gibson WC 1989. Hybridization with a repetitve DNA probe reveals the presence of small chromosomes in Trypanosoma vivax. Mol Biochem Parasitol 33: 35-142.

Felsenstein J 1985. Confidence limits on phylogenies: an approach utilizing the bootstrap. Evolution 39: 783-791.

Gonzalez A, Prediger E, Huecas ME, Nogueira N, Lizardi PM 1984. Minichromosomal repetitive DNA in Trypansoma cruzi: its use in a high-sensitivity parasite detection assay. Proc Natl Acad Sci USA 81: 3356-3360.

Jaccard P 1908. Nouvelles recherches sur la distribution florale. Bul Soc Vaudoise Sc Nat 44: 223-270.

Jarman AP, Wells RA 1989. Hypervariable minisatellites: recombinators or innocent bystanders? Trends Genet 5: 367-371.

Lanar DE, Levy L, Manning JE 1981. Complexity and content of the DNA and RNA in Trypanosoma cruzi. Mol Biochem Parasitol 3: 327-341.

Lewicka K, Brenière Campana SF, Barnabé C, Dedet JP Tibayrenc M 1995. An isoenzyme survey of Trypanosoma cruzi genetic variability in sylvatic cycles from french Guiana. Exp Parasitol 81: 20-28.

Macedo AM, Martins MS, Chiari E, Pena SDJ 1992. DNA fingerprint of Trypanosoma cruzi: a new tool for characterization of strains and clones. Mol Biochem Parasitol 55: 147-154.

Miles MA, Povoa M, De Souza AA, Lainson R, Shaw JJ, Ketteridge DS 1981. Chagas' disease in the Amazon Basin: II. The distribution of Trypanosoma cruzi zymodemes 1 and 3 in Pará State, north Brazil. Trans R Soc Trop Med Hyg 75: 667-674.

Miles MA, Souza A, Póvoa M, Shaw JJ, Lainson R, Toyé PJ 1978. Isozymic heterogeneity of Trypanosoma cruzi in the first autochthonous patients with
Chagas' disease in Amazonian Brazil. Nature 272: 819-821.

Miles MA, Toyé PJ, Oswald SC, Godfrey DG 1977. The identification by isoenzyme patterns of two distinct strain-groups of Trypanosoma cruzi circulating independently in a rural area of Brazil. Trans $R$ Soc Trop Med Hyg 71: 217-225.

Morel C, Chiari E, Camargo EA, Mattei DM, Romanha AJ, Simpson L 1980. Strains and clones of Trypanosoma cruzi can be characterized by pattern of restriction endonuclease. Proc Natl Acad Sci USA 77: 6810-6814.

Moser DR, Kirchhoff LV, Donelson JE 1989. Detection of Trypanosoma cruzi by DNA amplification using the Polymerase Chain Reaction. J Clin Microbiol 27: 1477-1482.

Ole-MoiYoi OK 1987. Trypanosome species-specific DNA probes to detect infection in Tsetse flies. Parasitol Today 3: 371-374.

Ready PD, Miles MA 1980. Delimitation of Trypanosoma cruzi zymodemes by numerical taxonomy. Trans R Soc Trop Med Hyg 74: 238-242.

Romanha AJ, Da Silva, Pereira AA, Chiari E, Kilgour V 1979. Isoenzyme patterns of cultured Trypanosoma cruzi: changes after prolonged subculture. Comp Biochem Physiol 62B: 139-142.

Sambrook J, Frisch EF, Maniatis T 1989. Molecular Cloning: a Laboratory Manual, 2nd ed., Cold Spring Harbor Laboratory Press, New York.

Sloof P, Bos JL, Konings AFJ, Menke HH, Borst P, Gutteridge WE, Leon W 1983. Characterization of satellite DNA in Trypanosoma brucei and Trypanosoma cruzi. J Mol Biol 167: 1-21.

Sokal RR, Sneath PH 1973. Principles of numerical taxonomy, p. 537. In D Kennedy, RB Park (eds), WH Freeman and Company, San Fransisco.

Souto RP, Fernandes O, Macedo AM, Campbell DA, Zingales B 1996. DNA markers define two major phylogenetic lineages of Trypanosoma cruzi. Mol Biochem Parasitol 83: 141-152.

Steindel M, Dias Neto E, Menezes CLP, Romanha AJ, Simpson AJG 1993. Random amplified polymorphic DNA analysis of Trypanosoma cruzi strains. Mol Biochem Parasitol 60: 71-80.

Tibayrenc M 1995. Population genetics of parasitic protozoa and other microorganisms, p. 47-115. In JR Baker, R Muller, D Rollinson (eds), Advances in Parasitology, Academic Press, London.

Tibayrenc M, Ayala F 1987. Forte corrélation entre classification isoenzymatique et variabilité de l'ADN kinétoplastique chez Trypanosoma cruzi. CR Acad Sci Paris 304: 89-92.

Tibayrenc M, Ayala FJ 1988. Isozyme variability in Trypanosoma cruzi, the agent of Chagas' disease: genetical, taxonomical, and epidemiological significance. Evolution 42: 277-292.

Tibayrenc M, Carriou ML, Solignac M, Carlier Y 1981. Arguments génétique contre l'existence d'une sexualité actuelle chez Trypanosoma cruzi; implications taxonomiques. CR Acad Sci Paris 293: 207209.

Tibayrenc M, Neubauer K, Barnabé C, Guerrini F, 
Skarecky D, Ayala FJ 1993. Genetic characterization of six parasitic protozoa: parity between random-primer DNA typing and multilocus enzyme electrophoresis. Proc Natl Acad Sci USA 90: 13351339.

Tibayrenc M, Solignac M, Cariou ML, Le Ray D, Desjeux P 1984. Les souches isoenzymatiques de Trypanosoma cruzi: origine récente ou ancienne, homogène ou hétérogène? CR Acad Sci Paris 299: 195-198.

Tibayrenc M, Ward P, Moya A, Ayala F 1986. Natural populations of Trypanosoma cruzi, the agent of Chagas' disease; have a complex multiclonal structure. Proc Nat Ac Sc USA 83: 115-119.

Véas F, Cuny G, Brenière SF, Tibayrenc M 1991. Subspecific kDNA probes for major clone of Trypanosoma cruzi. Acta Trop 48: 79-82. 